\title{
Recent hydrological droughts in Brazil and their impacts on energy security
}

Luz Cuartas ${ }^{1}$, Ana Paula Cunha ${ }^{1}$, Jessica Alves ${ }^{2}$, Larissa Pinto ${ }^{2}$, Karinne Deusdará Leal ${ }^{1}$, Lidiane Costa ${ }^{1}$, Ruben Molina ${ }^{3}$, Elisangela Broedel ${ }^{1}$, Pamela Araújo ${ }^{2}$, Marcelo Seluchi ${ }^{1}$, Diogo Amore ${ }^{1}$, Regina Alvalá ${ }^{1}$, and Jose Marengo ${ }^{1}$

${ }^{1}$ CEMADEN (National Center for Monitoring and Early Warning of Natural Disasters) ${ }^{2} \mathrm{UNESP}$

${ }^{3}$ University of Antioquia

September 25, 2021

\begin{abstract}
Brazil is heavily reliant on water resources. Hydroelectric plants generate about $64 \%$ of all electricity consumed. To increase yield capacity, a 2050 expansion is also planned. $78 \%$ of water used is for agriculture (irrigation and livestock), $9 \%$ for industry, and $9.1 \%$ for urban supply. However, the country has endured the worst droughts in recorded history over the last two decades, resulting in severe socioeconomic and environmental impacts. The purpose of this study was to determine the current state of knowledge regarding hydrological drought patterns, hydrometeorological factors, and their effects on the country's hydroelectric power plants. Droughts have occurred in most of Brazil's regions since 2014/15, causing severe impacts in many of the basins studied. Now that most hydroelectric power plants are operating at a fraction of their total capacity, the country's hydroelectric generation is been impacted.
\end{abstract}

\section{Hosted file}

Manuscript_Cuartas etal_HydrolDroughtsBrazil\&EnergySecurityBrazil.docx available https://authorea.com/users/436548/articles/538789-recent-hydrological-droughts-inbrazil-and-their-impacts-on-energy-security 

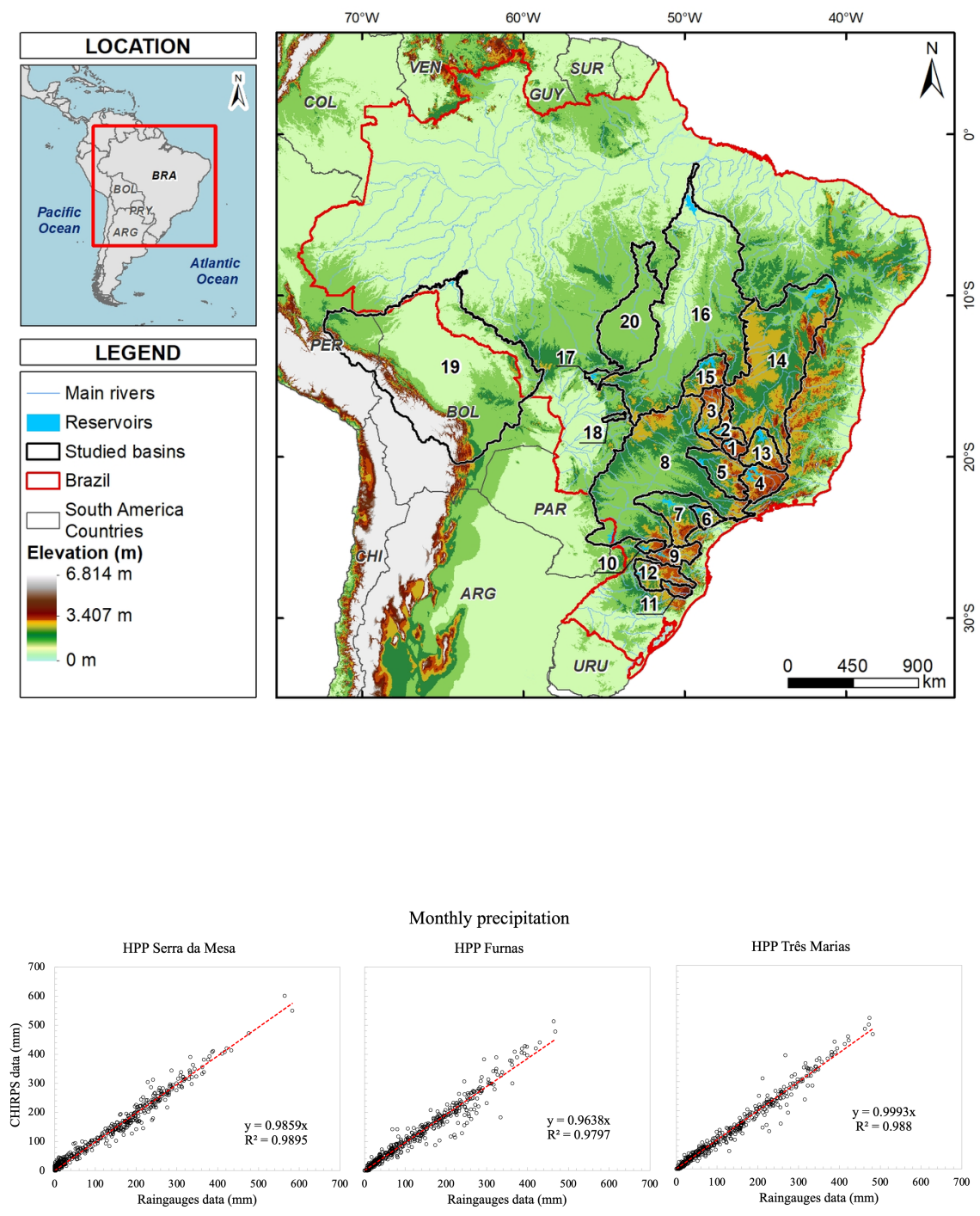


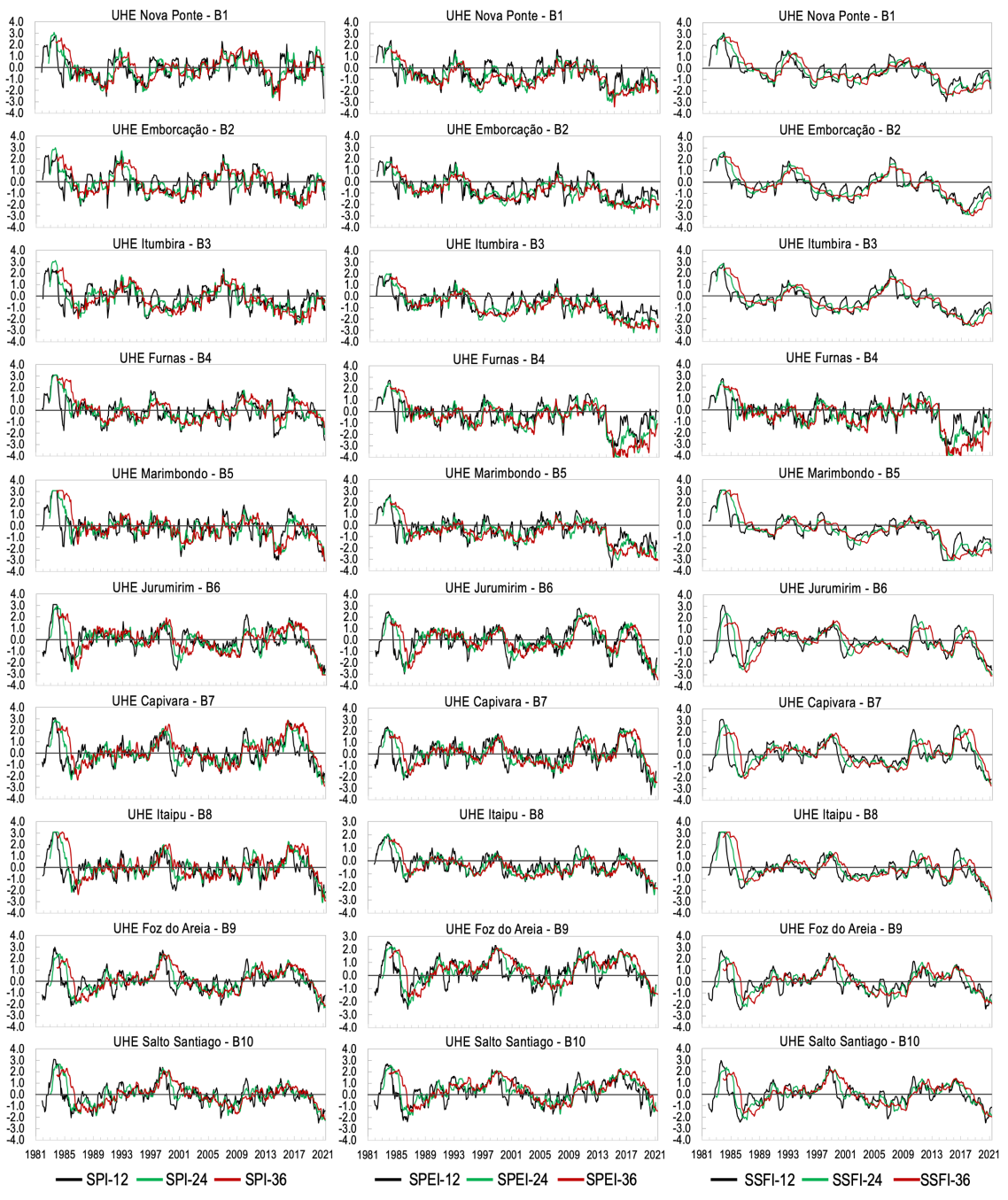




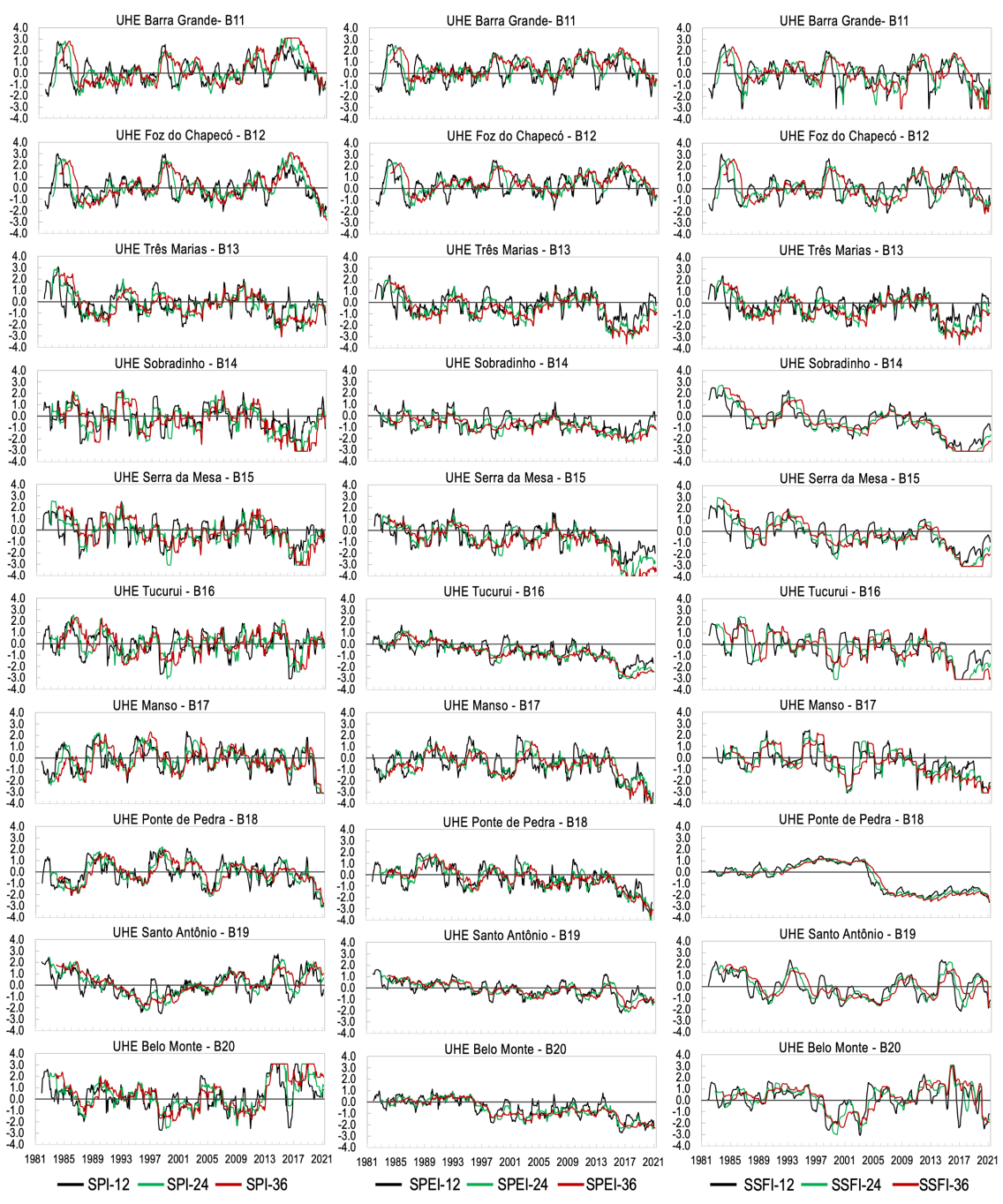



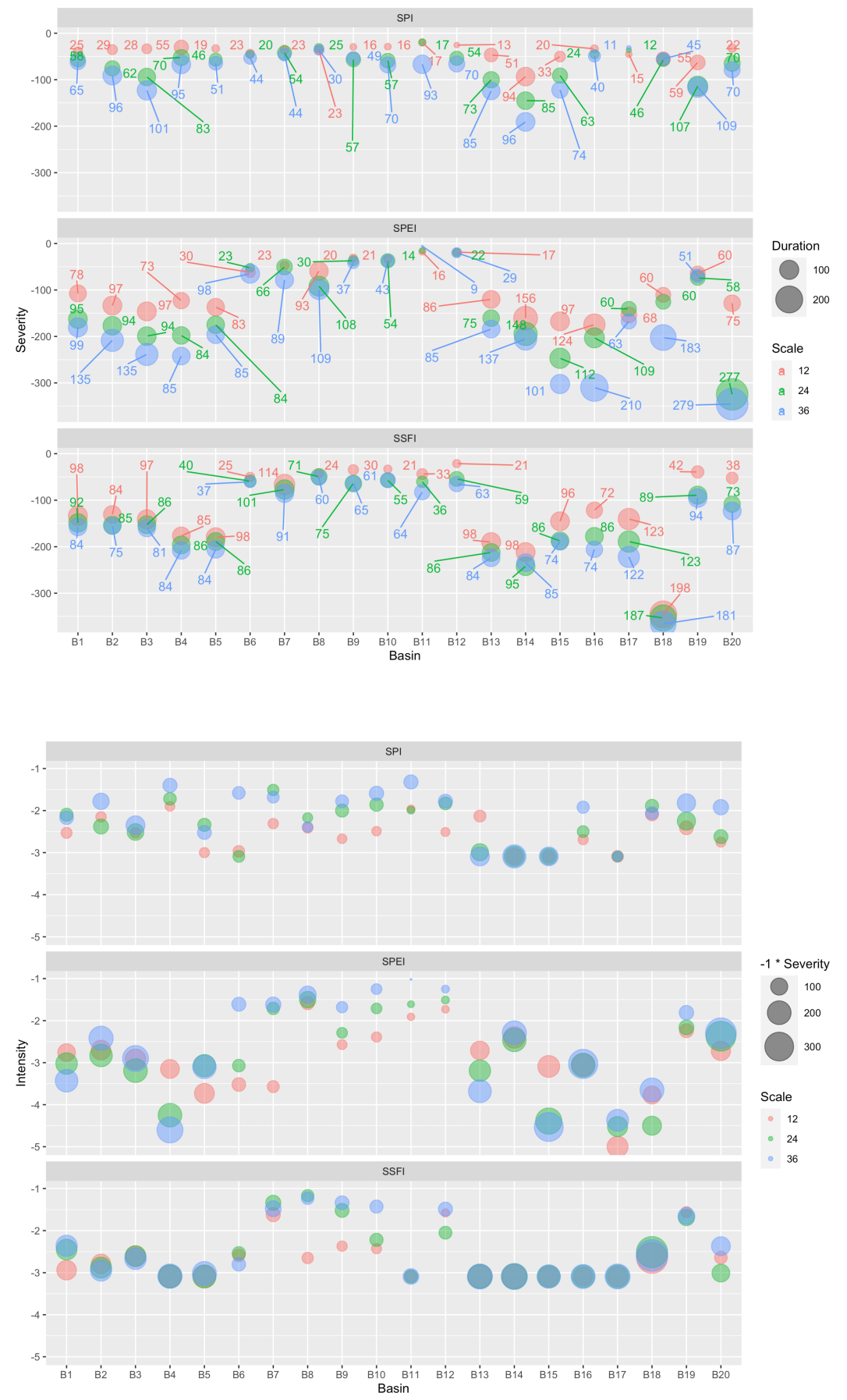


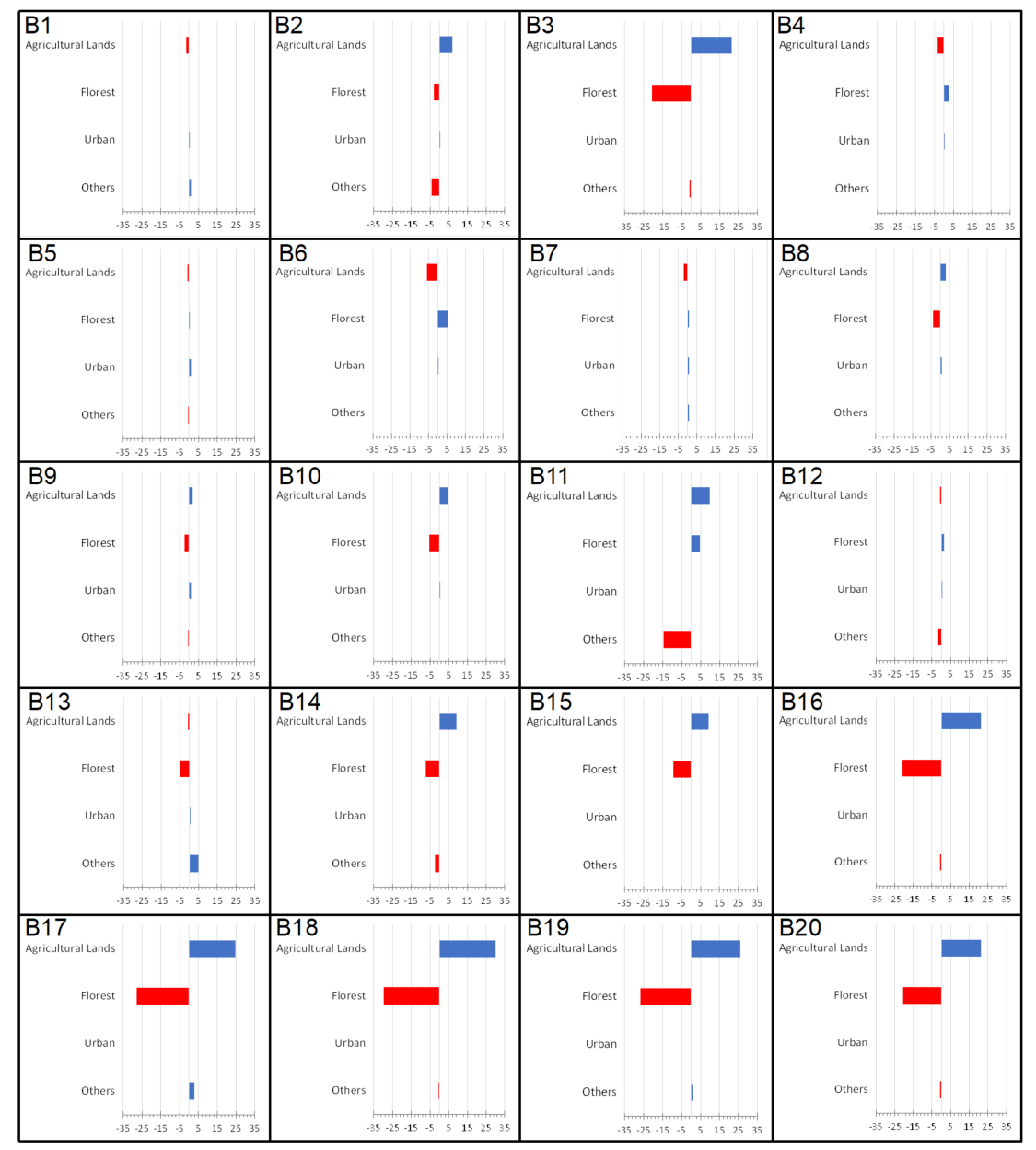



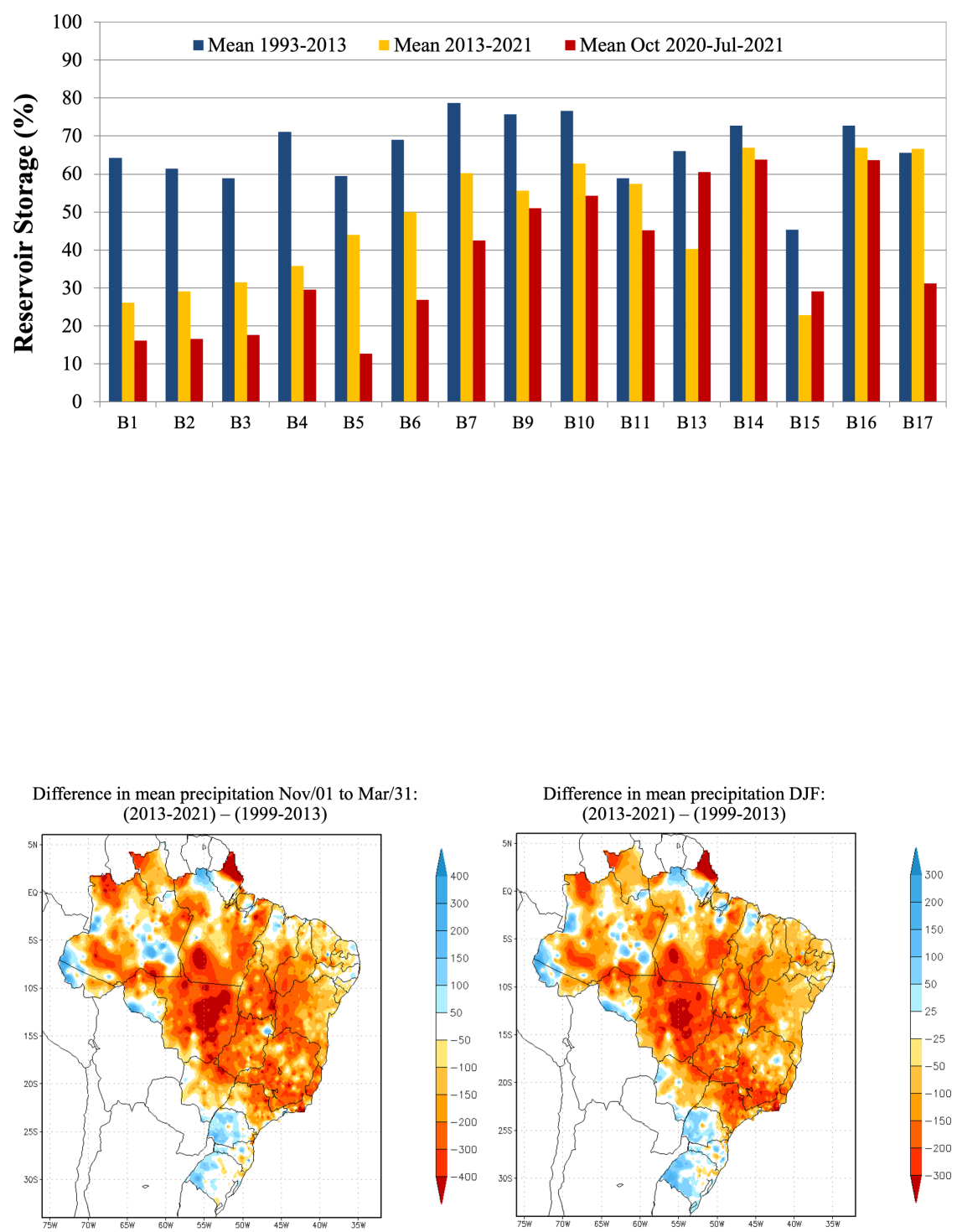

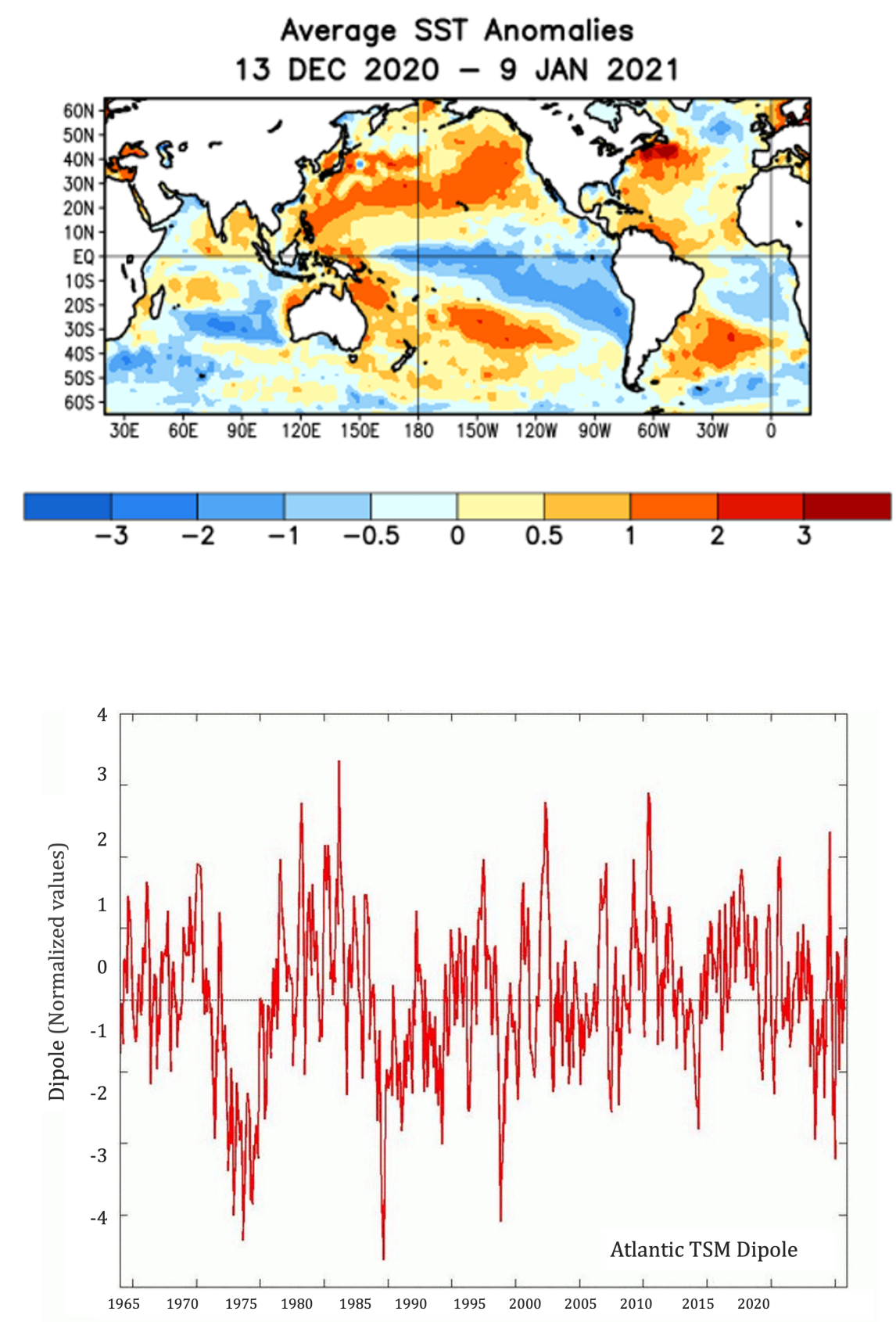

\section{Hosted file}

Table_1.docx available at https://authorea.com/users/436548/articles/538789-recenthydrological-droughts-in-brazil-and-their-impacts-on-energy-security

Hosted file

Table 2.docx available at https://authorea.com/users/436548/articles/538789-recenthydrological-droughts-in-brazil-and-their-impacts-on-energy-security 


\section{Hosted file}

Table_3.docx available at https://authorea.com/users/436548/articles/538789-recenthydrological-droughts-in-brazil-and-their-impacts-on-energy-security

Hosted file

Table_4.docx available at https://authorea.com/users/436548/articles/538789-recenthydrological-droughts-in-brazil-and-their-impacts-on-energy-security 